\begin{tabular}{|l|l|l||}
\hline \multicolumn{2}{|c|}{ PublisherInfo } \\
\hline \hline PublisherName & $:$ & BioMed Central \\
\hline \hline PublisherLocation & $:$ & London \\
\hline \hline PublisherImprintName & $:$ & BioMed Central \\
\hline \hline
\end{tabular}

\title{
Serum amyloid P component prevents antinuclear autoimmunity
}

\begin{tabular}{||l|l|l||}
\hline \multicolumn{2}{|c||}{ ArticleInfo } \\
\hline \hline ArticleID & $:$ & 242 \\
\hline \hline ArticleDOI & $:$ & $10.1186 /$ ar-1999-66729 \\
\hline \hline ArticleCitationID & $:$ & 66729 \\
\hline \hline ArticleSequenceNumber & $:$ & 199 \\
\hline \hline ArticleCategory & $:$ & Paper Report \\
\hline ArticleFirstPage & $:$ & 1 \\
\hline \hline ArticleLastPage & $:$ & 4 \\
\hline \hline & $:$ & RegistrationDate : 1999-9-6 \\
ArticleHistory & $:$ & OnlineDate \\
\hline \hline ArticleCopyright & $:$ & Current Science Ltd1999-9-6 \\
\hline \hline ArticleGrants & $:$ & \\
\hline \hline ArticleContext & $:$ & 130753311 \\
\hline \hline
\end{tabular}


Aff1 Imperial College School of Medicine, London, UK

\section{Keywords}

Autoimmunity, chromatin, glomerulonephritis, serum amyloid P component (SAP)

\section{Context}

Serum amyloid P component (SAP), a highly conserved plasma protein named for its universal presence in amyloid deposits, is the single normal circulating protein that shows specific calciumdependent binding to DNA and chromatin in physiological conditions. The avid binding of SAP displaces H1-type histones and thereby solubilizes native long chromatin, which is otherwise profoundly insoluble at the physiological ionic strength of extracellular fluids. Furthermore, human SAP binds in vivo both to apoptotic cells, the surface blebs of which bear chromatin fragments, and to nuclear debris released by necrosis. SAP may therefore participate in the handling of chromatin exposed by cell death. To investigate the physiological role of SAP in vivo.

\section{Significant findings}

SAP-/- mice spontaneously produced autoantibodies and, predominantly in females, developed a severe proliferative glomerulonephritis. At 8 months SAP-/- mice had a significantly higher incidence of antibodies to nuclear components, chromatin, histones, single-stranded DNA and double-stranded DNA compared to wild-type mice. The histological severity of the glomerulonephritis was significantly greater in the female (but not the male) SAP-/- mice compared to wild-type mice.

Immunization with native long chromatin induced anti-nuclear antibodies in both wild-type and SAP/- mice. However, titres of anti-double-stranded-DNA antibodies, 44 days following immunization, were significantly higher in SAP-/- mice compared to wild-type controls. Following intraperitoneal injection, the rate of degradation of radio-iodinated native long chromatin was significantly faster in SAP-/-

female mice compared to controls. Furthermore, the rate was normal in C1qa-/- mice, demonstrating the classical pathway of complement activation is not involved in this process.

In experiments with native long chromatin incubated with human monocytes or neutrophils the presence of SAP retarded the internucleosomal cleavage of DNA, an effect that was not seen with human C-reactive protein (CRP). Furthermore, incubation of long chromatin with mouse peritoneal 
exudate cells and SAP-sufficient or SAP-deficient mouse serum showed that DNA cleavage was faster in the absence of SAP. Therefore, both mouse and human SAP appeared to protect DNA from cleavage in vitro.

\section{Comments}

This is an outstanding and exciting publication demonstrating that SAP is critical in the nonimmunogenic processing of chromatin and prevention of autoimmunity in mice. It is a clear vivo demonstration that the breakdown of a physiological mechanism for the clearance of an autoantigen can result in autoimmunity. What is the relevance of these findings to the pathogenesis of SLE in humans? Clearly, further study into the function of SAP in patients with SLE is indicated. Circulating levels of SAP in SLE patients are normal but defects in its regulation or function may be present. Furthermore, although SAP is the main acute phase protein in the mouse, in humans it is the related pentraxin, CRP. Analogous to the role of SAP in chromatin clearance, CRP may be important in the non-immunogenic processing of its ligands. Notably, during disease flares of SLE rises in CRP characteristically do not occur (except in the presence of infection). This may result in the failure of the physiological nonimmunogenic

processing of autologous ligands and consequent development of autoimmunity.

\section{Methods}

SAP-/- mice were produced on the hybrid (129/Sv x C57BL/6) genetic background as described previously (Botto M et al, Nat Med 1997, 3:855-859 [Abstract]). Antibodies against chromatin, singlestranded DNA and histones were assayed by ELISA. Antinuclear and anti-double-stranded-DNA antibodies were assayed by indirect immunofluorescence on Hep-2 cells and Crithidia luciliae respectively.

Mice were immunized by intramuscular injection of 100 micrograms of avian erythrocyte native long chromatin (emulsified in either complete or incomplete Freund?s adjuvant). Blood samples were taken at baseline and weekly intervals following immunization.

Chromatin degradation in vivo was assessed by administering iodinated native long chromatin from avian erythrocytes intraperitoneally and measuring whole body radioactivity immediately and at intervals up to 24 hours. In these experiments mice were 8 weeks old and did not have autoantibodies.

Chromatin degradation in vitro was assessed by incubating native avian erythrocyte long chromatin at

$37^{\circ} \mathrm{C}$ with $2 \times 10^{6}$ peritoneal exudate cells collected from C57BL/6 mice after elicitation with oyster glycogen. The cells and chromatin were suspended in media and 50\% v/v mouse serum (derived from either wild-type or SAP-/- mice). Following incubation up to 3 hours, the DNA was extracted and 
separated on agarose and the intensity of bands corresponding to monosomes and higher-order structures was quantitated.

\section{References}

1. Bickerstaff MC, Botto M, Hutchinson WL, Herbert J, Tennent GA, Bybee A, Mitchell DA, Cook HT, Butler PJ, Walport MJ, Pepys MB: Serum amyloid P component controls chromatin degradation and prevents antinuclear immunity. Nat Med. 1999, 5: 694-697.

This PDF file was created after publication. 